\title{
PENERAPAN DIVERSI TERHADAP ANAK YANG MELAKUKAN TINDAK PIDANA
}

\author{
Hulman Panjaitan \\ Lonna Yohanes Lengkong \\ Fabianustua Sihaloho \\ hulman234@yahoo.com \\ Universitas Kristen Indonesia, Jakarta, Indonesia
}

\begin{abstract}
Diversity implementation by law enforcers is based on the authority of law enforcers called the discretion or discretion of children as the potential of the State in the context of the survival and glory of the nation, is how the government's commitment to make children a top priority in the development of juvenile judges and courts as the last stronghold in the process settlement of children who are fac-ing law in the Court. The police and the community must synergize and develop the same perception of diversion and restorative justice. Parents must participate in providing protection for children by fulfilling children's rights, protecting the interests of children and further increasing supervision of the environment and where children play
\end{abstract}

Keywords: diversity; implementation; children.

\section{Pendahuluan}

Anak adalah bagian yang tidak terpisahkan dari keberlangsungan hidup manusia dan keberlangsungan sebuah bangsa dan negara. Dalam konstitusi Indonesia, anak memiliki peran strategis yang secara tegas dinyatakan bahwa negara menjamin hak setiap anak atas keberlangsungan hidup, tumbuh dan berkembang serta atas perlindungan dari kekerasan dan diskriminasi. Oleh karena itu kepentingan terbaik bagi anak patut dihayati sebagai kepentingan terbaik umat manusia.1

Anak perlu mendapat perlindungan dari dampak negatif perkembangan pembangunan yang cepat, arus globalisasi di bidang komunikasi dan informasi, kemajuan ilmu pengetahuan dan teknologi, serta perubahan gaya dan cara hidup sebagian orang tua yang telah membawa perubahan sosial yang mendasar

1 Lembaga Bantuan Hukum Jakarta,Mengawal Perlindun-gan Anak Berhadapan Dengan Hukum, CetakanKesatu, Jakarta, LBH Jakarta, 2012, hlm 11 dalam kehidupan masyarakat yang sangat berpengaruh terhadap nilai dan perilaku anak.

Tidak bisa dipungkuri bahwa kehidupan anak sangat bergantung pada siapa yang merawat atau mengasuhnya dan dimana ia dibesarkan. Dalam hal ini dapat digambarkan sebagai kertas putih yang tergan-tung pada orang dewasa yang hendak menggoreskan tulisan.

Hal ini tidak jauh berbeda seperti yang ditunjukkan dalam deklarasi anak-anak, karena anak belumlah dewasa secara fisik dan mental,maka ia memerlukan pengawalan dan perlindungan khusus,termasuk perlindungan legal yang layak,sebelum dan sesudah lahir.2

Dalam konteks inilah negara berkewajiban untuk memberikan perlindungan terhadap anak sebagaimana kewajibannya untuk menghargai (torespect); melind-

\footnotetext{
2 Nashriana, PerlindunganHukumPidanaBagiAnak di Indonesia, (Jakarta, PT. Raja Grafindo Persada,2011), hal. 76.
} 
ungi (to protect); dan memenuhi (to fullfil) kebutuhan hidup anakbaik secara fisik maupun psikis. Hak-hak anak yang seharusnya dipenuhi dan mendapatkan jaminan perlindungan adalah hak-hak anak mencakup empat bidang yakni agama; pendidikan; kesehatan dan sosial, sebagaimana telah diatur dalam UU No. 35 Tahun 2014 Tentang perubahan atas UU No. 23 Tahun 2002 Tentang Perlindungan Anak.

Dalam relasinya dengan hukum, perlakuan terhadap anak juga mendapatkan perhatian yang khusus. Demikian pula jika anak bersentuhan dengan hukum pidana. Anak yang berkonflik dengan hukum maupun anak yang terposisikan sebagai korban tidak semestinya menjadi alasan untuk yang terposisikan sebagai korban tidak semestinya menjadi alasan untuk memperlakukan anak sama dengan orang dewasa. Hal ini dikarenakan anak memiliki kesadaran kognitif (mens rea) yang berbeda dengan orang dewasa. Namun bukan berarti anak tidak memiliki kecakapan hukum yang dapat menghilangkan hak hukumnya seperti yang dinyatakan dalam bidang hukum keperdataan.

Harus ada pertimbangan khusus untuk melibatkan anak dalam menentukan dirinya sendiri serta kepentingan yang terbaik bagi diri anak. Asas inilah yang biasa disebut dengan hak partisipasi anak. Meskipun secara psikologis anak memiliki ketergantungan yang besar pada orang dewasa tetapi prisip tersebut harus menjadi titik tekan bahwa anak memiliki hak-hak khusus secara manusiawi yang harus mendapat perlindungan.

Anak merupakan harapan bangsa dan calon pemimpin di masa depan, Namun, seringkali anak justru dihadapkan dengan proses hukum Yng berujung sampai hukuman penjara bertahun-tahun. Tindak pidana yang dilakukan oleh anak tentunya diakibatkan oleh berbagai faktor, terutama faktor kondisi ekonomi, pendidikan, dan sosial Indonesia yang terpuruk sehingga mendorong mereka untuk melakukan kejahatan. Berangkat dari hal tersebut, maka anak yang berhadapan dengan hukum yang sering disebut sebagai "anak nakal" haruslah dimaknai sebagai korban.3

Tidak hanya menjadi korban yang mendorong mereka untuk berbuat kejahatan, anak kemudian kembali menjadi korban ketika sudah berhadapan

3 M. Nasir Djamil, 2013, AnakBukanuntukDihukum, Jakarta, Sinar Grafika. Hlm. 3 dengan hukum atau sistem peradilan.Anak tidak hanya kehilangan kebebasannya,namun seringkali kehilan-gan hak-haknya yang lain seperti tidak mendapatkan bantuan hukum ataupun pendamping, mendapatkan penyiksaan, pelecehan, ditempatkan dalam penjara yang sama dengan orang dewasa, tidak diperbolehkan untuk dikunjungi, tidak mendapatkan pendidikan, hiburan,dll.

Indonesia sebenarnya telah mengadopsi maupun meratifikasi konvensi-konvensi internasional yang berkaitan dengan perlindungan anak, seperti Convention on The Right of The Child.Selain itu Indonesia telah membuat Undang-Undang yang berkaitan dengan perlindungan anak seperti Undang-Undang Nomor 4 Tahun 1979 tentang kesejahteraan anak, UndangUndang Nomor 3 Tahun 1997 tentang pengadilan anak, dan Undang-Undang Nomor 35 Tahun 2014 tentang perubahan atas UU No 23 Tahun 2003 tentang perlindungan anak.Namun keseluruhan peraturan tersebut sangat lemah dalam implementasi dan juga membutuhkan perbaikan yang jauh lebih maju.

Untuk memecahkan permasalahan anak yang berhadapan dengan hukum,maka diwacanakanlah konsep keadilan restoratif,yaitu konsep pemidanaan yang mengedepankan pemulihan kerugian yang dialami korban dan pelaku,dibanding menjatuhkan hukuman penjara bagi pelaku.Konsep tersebut belum sepenuhnya diadopsi dalam sistem peradilan anak di Indonesia dan rencananya akan dimasukkan dalam Rancangan Undang-Undang (RUU) sisterm Peradilan Pidana Anak,sehingga mebutuhkan dorongan masyarakat dan pengawasan masyarakat untuk pelaksanaannya.

Undang-undang No.3 Tahun 1997 Tentang Pengadilan Anak menyebutkan tentang "anak yang berkonflik dengan hukum". Anak yang berkonflik dengan hukum dilatarbelakangi oleh lingkungan sosial dimana ia hidup, tumbuh dan berkembang. Lingkungan sosial inilah yang menjadi tempat anak melakukan kegiatan hariannya, lingkungan sosial ini yang selalu dilihat, didengar dalam pengalaman anak. Oleh karena itu, tidak dapat dipungkuri bahwa lingkungan sosial dapat menjadi faktor yang memungkinkan anak melakukan tindakan kekerasan, yang dalam banyak kasus sering masuk dalam kategori tindak pidana (delict).

Selama proses pemeriksaan, anak yang sedang 
berkonflik dengan hukum dipaksa mengikuti prosedur yang lazim diikuti oleh orang dewasa. Situasi ini memungkinkan anak berada dalam keterpaksaan dimana ia harus melalui proses pemeriksaan yang telah menjadi kebiasaan dari oknum kepolisian dalam melakukan penyidikan maupun penyelidikan dalam menangani kasus pidana.

Dalam konsepnya, perlindungan anak tidak hanya meliputi perlindungan atas hak-haknya saja tetapi juga berkaitan dengan aspek pembinaan generasi muda, dengan memperhatikan bahwa anak-anak bukanlah individualis sebab anak masih sangat tergantung pada orang dewasa, terutama orang dewasa yang mereka kenal, disamping juga adanya fakta bahwa anak belum dapat menghidupi dirinya sendiri.

Hukum yang mengatur tentang anak harus lebih mengutamakan perlindungan terhadap hak-hak asasi anak sebagaimana yang telah diatur di beberapa ke-tentuan yang berlaku, yang beberapa diantaranya telah diperbaiki menjadi hukum nasional. Piagam Afrika adalah salah satu peraturan yang merupakan kesepaka-tan dari beberapa negara. Pasal 1 Angka (3) Piagam Af-rika ini menegaskan tentang pelarangan pemberlakuan segala bentuk praktik yang telah menjadi kebiasaan, kultur dan keyakinan atau kepercayaan (religi) yang bertentangan dengan prinsip non-diskriminasi, kebe-basan berekspresi dan pendidikan anak.

Terkait dengan kasus hukum,seperti halnya orang dewasa,anak-anak bisa berkedudukan sebagai pelaku (tersangka,terdakwa) maupun sebagai korban.Di dalam kedudukannya sebagai korban,anak bisa sebagai korban langsung,misalnya sebagai korban pemerkosaan,juga sebagai korban tidak langsung,contohnya adalah anak terlantar karena orang tua masuk penjara terlibat kasus narkoba.Di dalam kasus ada sebagai pelaku,penelitian yang ada menunjukkan bahwa kebanyakan anak yang terlibat sebagai pelaku kejahatan,terutama kriminal memiliki orang tua yang kurang memiliki keterampi-lan pengasuhan yang baik.

Pendamping dari sosok autoritas yang bisa memberikan keamanan dan perlindungan juga sangat dibutuhkan.Begitu juga ketika anak dianggap sebagai pelaku tindak kejahatan.Lembaga rehabilitasi anak hendaknya juga tidak melupakan kebutuhan anak untuk berkembang secara fisik.kognitif,psikologi dan so-
sial.Terkait dengan kemampuan sosial.pola asuh orang dewasa disekitar anak jangan pernah melupakan tugas utama perkembangan anak yaitu membangun kepercayaan dengan lingkungan sekitar serta menumbuhkan kemandirian.Berdasarkan uraian diatas, banyaknya tindakan kriminal yang dilakukan oleh anak yang menyebabkan perilaku menyimpangnya,maka penulis merumuskan pokok permasalahan mengenai agaimana penerapan diversi terhadap anak yang melakukan tindak pidana dan penerapan putusan nomor 14/ PID.Sus-Anak/2015/PT.MDN terhadap anak yang melakukan tindak pidana. Untuk mengetahui secara jelas bagaimana penerapan diversi terhadap anak yang melakukan tindak pidana dan mengetahui secara jelas bagaimana putusan tersebut diterapkan terhadap anak yang melakukan tindak pidana.

\section{Pembahasam}

\section{Tinjauan umum tentang Tindak}

\section{Pidana Pengertian Tindak Pidana}

Pengertian tindak pidana dimuat dalam Kitab Undang-Undang Hukum Pidana ( KUHP ) yang sering disebut strafbaar feit. Istilah strafbaar feit merupakan bahasa Belanda terdiri dari 3 kata, yaitu straf yang berarti hukuman (pidana), baar yang berarti dapat (boleh), dan feit yang berarti tindak, peristiwa, pelanggaran dan perbuatan. Jadi istilah strafbaar feit adalah peristiwa yang dapat dipidana atau perbuatan yang dapat dipidana. Tindak Pidana adalah perbuatan yang dilarang oleh suatu aturan hukum, larangan mana disertai ancaman (sanksi) yang berupa pidana tertentu, bagi siapa yang melanggar aturan tersebut.

Terdapat 3 (tiga) hal yang perlu diperhatikan:

1. Perbuatan pidana adalah perbuatan oleh suatu aturan hukum dilarang dan diancam pidana.

2. Larangan ditujukan kepada perbuatan yaitu suatu kejadian yang ditimbulkan oleh kelakuan orang), sedangkan ancaman pidana ditujukan kepada orang yang menimbulkan kejadian itu.

3. Antara larangan dan ancaman pidana ada hubungan yang erat, oleh karena antara kejadian dan orang yang menimbulkan kejadian itu aa hubungan erat pula. "Kejadian tidak dapat dilarang jika yang menimbulkan bukan orang, dan orang tidak 
dapat diancam pidana jika tidak karena kejadian yang ditimbulkan olehnya".

Menurut Pompe yang dikutip Bambang Poernomo, pengertianStrafbaar feit dibedakan menjadi :

1. Defenisi menurut teori adalah suatu pelanggaran terhadap norma yang dilakukan karena kesalahan si pelanggar dan diancam dengan pidana untuk mempertahankan tata hukum dan menyelamatkan kesejahteraan umum.

2. Definisi menurut hukum positif adalah suatu kejadian/feit yang diancam pidana.

"Delik" berasal dari bahasa latin, yakni delictum. Dalam bahasa Jerman disebut delict, dalam bahasa Prancis disebut delit, dan dalam bahasa Belanda disebut delict. Sementara dalam kamus besar Bahasa Indonesia arti delik diberi batasan yaitu : " perbuatan yang dapat dikenakan hukum karena merupakan pelanggaran terhadap undang-undang tindak pidana “..4

\section{Tinjauan Umum Tentang Tindak Pidana Persetu- buhan}

\section{Pengertian Tindak Pidana Persetubuhan}

Perbuatan persetubuhan merupakan tindak pidana kesusilaan,menurut kamus hukum pengertian kesusilaan diartikan sebagai tindakah laku, perbuatan percakapan bahwa sesuatu apapun yang berpautan dengan norma-norma kesopanan yang harus dilindungi oleh hukum demi terwujudnya tata tertib dan tata susila dalam kehidupan bermasyarakat.

Pengertian persetubuhan menurut R. Soesilo adalah perpaduan antara kelamin laki-laki dan kelamin perempuan yang biasanya dijalankan untuk mendapatkan anak, jadi anggota kemaluan laki-laki harus masuk ke dalam anggota kemaluan perempuan sehingga mengeluarkan air mani.s

Persetubuhan diatur dalam KUHP Buku II tindak pidana kesusilaan. Dalam Pasal 285Pasal 286 Pasal 287 danPasal 288 KUHP, ketentuanPasal 287 KUHP

4 Sudarsono, KamusHukum, CetakanKelima, Jakarta, P.T. RinekaCipta, 2007, hlm 92

5 C.S.T. Kansil dan Christine S.T. Kansil, Pokok-Pokok Hukum Pidana (Jakarta: PT. Pradnya Paramita, 2007) hlm. 41 yang korbannya disyaratkan adalah anak yang belum berusia 15 tahun dan antara korban dan pelaku tidak terdapat hubungan pernikahan.6

\section{Pengertian Konsep Diversi}

Anak yang melakukan pelanggaran hukum atau melakukan tindakan kriminal sangat dipen-garuhi beberapa faktor lain di luar diri anak seperti pergaulan,pendidikan,teman bermain dan sebagainya. Untuk melakukan perlindungan terhadap anak dari pengaruh proses formal sistem peradilan pidana, maka timbul pemikiran manusia atau para ahli hukum dan kemanusiaan untuk membuat aturan formal tindakan mengeluarkan seorang anak yangmelakukan pelanggaran hukum atau melakukan tindak pidana dari proses peradilan pidana dengan memberikan alternatif lain yang dianggap lebih baik untuk anak. Berdasarkan pikiran tersebut, maka lahirlah konsep diversion yang dalam istilah bahasa Indonesia disebut diversi atau pengalihan.

Upaya perlindungan hukum terhadap anak yang berhadapan dengan hukum perlu yang secara terus menerus diupayakan demi tetap terpeliharanya kesejahteraan anak mengingat anak merupakan salah satu aset berharga bagikemajuan suatu bangsa di kemudian hari. Perlindungan hukum bagi anak yang berhadapan dengan hukum dapat di artikan sebagai upaya perlindungan hukum terhadap berbagai kebebasan dan hak asasi anak. Jadi masalah perlindungan hukum bagi anak mencakup lingkup yang sangat luas.

Hak-hak anak menurut UU NO 35 tahun 2014 tentang perubahan atas UU NO 23 tahun 2002 tentang perlindungan anak yang terdapat dalam pasal 4 (empat) sampai dengan pasal 18 (delapan belas).

Kesepakatan Diversi untuk menyelesaikan tindak pidana yang berupa pelanggaran, tindak pidana ringan, tindak pidana tanpa korban, atau nilai kerugian korban tidak lebih dari nilai upah minimum provinsi setempat sebagaimana dimaksud dalam pasal 9 ayat (2) dapat dilakukan oleh penyidik bersama pelaku dan/atau

6 BadanKoordinasiKeluargaBerencana Nasional. 2002. Pelecehan SeksualoKekerasan Seksual. Jakarta : BKKBN. 
keluarga, pembimbing kemasyarakatan, serta dapat melibatkan tokoh masyarakat.7

\section{Tujuan Diversi}

Menurut Levine konsep diversi dimulai dengan pendirian peradilan anak pada abad ke-19 yang bertujuan untuk mengeluarkan anak dari proses peradilan orang dewasa agar anak tidak lagi diperlakukan sama dengan orang dewasa. Prinsip utama pelaksanaan konsep diversi yaitu tindakan persuasif atau pendekatan non penal dan memberikan kesempatan kepada seseorang untuk memperbaiki kesalahan. Petugas dalam melaksanakan diversi menunjukkan pent-ingnya ketaatan kepada hukum dan aturan. Petugas melakukan diversi dengan cara pendekatan persuasif dan menghindari penangkapan yang menggunakan tindakan kekerasan dan pemaksaan.8

Diversi dilakukan dengan alasan untuk memberikan suatu kesempatan kepada pelanggar hukum agar menjadi orang yang baik kembali melalui jalur non formal dengan melibatkan sumber daya masyarakat. Diversi berupaya memberikan keadilan kepada kasus anak yang telah terlanjur melakukan tindak pidana sampai kepada aparat penegak hukum sebagai pihak penegak hukum. Kedua keadilan tersebut dipaparkan melalui sebuah penelitian terhadap keadaan dan situasi untuk memperoleh sanksi atau tindakan yang tepat (appropriate treatment).

Tiga jenis pelaksanaan program diversi yaitu.

1. Pelaksanaan kontrol secara sosial (social control orientation),

2. Pelayanan sosial oleh masyarakat terhadap pelaku (social serviceorientation

3. Menuju proses restorative justice atau perundingan (balanced orrestorative justice orientation.

7 Maidin Gultom, Perlindungan Hukum Terhadap Anak Dalam Sistem Peradilan Pidana Anak di Indonesia,Redika Aditama, Bandung, 2010, hlm. 7

8 Wagiati soetodjo,2006,hukum pidana anak,Bandung:refika aditama,hal.72.
Pelaksanaan Diversi

Pelaksanaan diversi oleh aparat penegak hukum didasari oleh kewenangan aparat penegak hukum yang disebut discretion atau dalam bahasa Indonesia diskresi.

Polisi sebagai gerbang pertama yang menangani anak yang berkonflik dengan hukum menjadi penentu apakah seorang anak akan dilanjutkan ke proses peradilan atau tindakan informal lainnya. Untuk tindak pidana yang serius seperti pembunuhan, pemerko-saan, pencurian dengan kekerasan, polisi melanjutkan proses ke pengadilan atau melakukan penahanan. Anak dibedakan tempat penahannya dengan orang dewasa pemenuhan fasilitas yang melindungi perkemban-gan anak, pendidikan, hobi, akses dengan keluarga, perlindungan hak propesi anak, pelindungan dari penyiksaan dan perlakuan fisik dan mental dan proses peradilan yang singkat dancepat.9

Anak pelaku tindak pidana yang menurut penilaian keseriusan tindak pidananya selanjutnya akan diproses oleh pihak penuntut umum untuk dilanjutkan ke proses persidangan. Jaksa penuntut umum setelah mendapatkan laporan dari penyidik tentang kasusnya maka penuntut umum membuat rencana penuntutan terhadap kasus tersebut. Penuntut umum dalam melakukan penuntutan awalnya mengajukan rencana tuntutan terhadap anak untuk diserahkan kepada pimpinan selanjutnya pimpinan akan memberikan tanggapan atas rencana penuntutan yang diajukan. Keputusan tuntutan yang telah disetujui inilah yang akan diajukan ke lembaga pengadilan sebagai proses pelimpahan perkara dari penuntut umum ke pihak pengadilan.10

Pengadilan anak mempunyai fungsi khusus, kekhususan itu secara normatif dicerminkan hakim yang dapat menyidangkan perkara anak diangkat se-cara khusus artinya tidak semua hakim dapat mengadili perkara anak, kemudian kekhususan juga terletak acarapersidangan (hukum acaranya), hakim tidak boleh

9 Kenneth Polk, dalam Made AyuCatra MS, DiversidalamSistemPeradilanPidanaAnakdi Indonesia, Thesis, Denpasar: Program PascasarjanaUdayana, hlm. 6

10Irina Styowati, 1990, AspekHukumPerlindunganAnak, Jakarta: BumiAksara. 
pakai toga, jaksa tidak boleh memakai pakaian dinas. Pemeriksaan anak di persidangan diwajibkan untuk didampingi oleh pendamping, pendamping itu bukan pengacara melainkan lembaga dan proses persidangan tertutup serta pemeriksaan dengan hakim tunggal.

Pelaksanaan konsep diversi dilakukan dengan tujuan menghindarkan anak dari implikasi negatif sistem peradilan pidana yang ada, menghindarkan anak akan masuk sistem peradilan pidana anak dan menghilangkan label penjahat terhadap anak yang telah terlanjur menjadi korban dari sistem dan perkem-bangan lingkungan pergaulan yang ada. Konsep di-versi dikembangkan hampir diseluruh negara, karena konsep diversi ini menunjukan adanya keberhasilan dalam menyelamatkan dan memberikan perlindungan terhadap anak.11

\section{Perlindungan bagi anak yang \\ Berhadapan dengan Hukum}

Perlindungan khusus bagi anak yang berhadapan dengan hukum dilakukan melalui; perlakuan secara manusiawi dengan memperhatikan kebutuhan sesuai dengan umurnya; pemisahaan dari orang dewasa; pemberian bantuan hukum dan bantuan lain secara efektif; pemberlakuan kegiatan rekreasional; pembebasan dari penyiksaan,penghukuman, atau perlakuan lain yang kejam, tidak manusiawi serta merendahkan martabat dan derajatnya; penghindaran dari penjatuhan pidana mati dan/atau pidana seumur hidup; penghindaran dari penangkapan, penahanan atau penjara, kecuali sebagai upaya terakhir dan dalam waktu yang paling singkat; pemberian keadilan di muka pengadilan anak yang objektif, tidak memihak, dan dalam sidang yang tertutup untuk umum; penghindaran dari publikasi atas identitasnya; pemberian pendampingan orangtua/wali dan orang yang dipercaya oleh anak; pemberian advokasi sosial; pemberian kehidupan pribadi; pemberian aksebilitas, terutama bagi anak penyandang Disabilitas; pemberian pendidikan; pemberian pelayanan keseha-

11R. Wiyono, SistemPeradilanPidanaAnak di Indonesia, Jakarta: SinarGrafika, 2016, hlm. 47 tan; dan pemberian hak lain sesuai dengan ketentuan peraturan perundang-undangan. 12

Pasal 18 UU No. 23 tahun 2002 menyebutkan,setiap anak yang menjadi korban atau pelaku tindak pidana berhak mendapatkan bantuan hukum danbantuan lainnya. Dalam bagian penjelasan atas UU No. 23 tahun 2002 tersebut dikatakan, bantuan lainnya da-lam ketentuan ini termasuk bantuan medis, sosial, rehabilitasi, vokasional dan pendidikan. Setiap kasus yang masuk ke kepolisian, jika sang pelaku belum didampingi oleh kuasa hukum maka tim RPK Polda berkewajiban melaporkannya kepada institusi LBH Anak, sehinggaanak yang menjadi pelaku ataupun korban tindak pidana bisa mendapat pendampingan dan bantuan hukum.

Proses pengadilan anak akan dilakukan berbeda dengan proses pengadilan biasa. Dalam setiap persidangan majelis hakim akan hadir sebagai penengah dan pemberi nasihat, tanpa menggunakan seragam hakim dan atribut lainnya. Hal ini dilakukan untuk menjaga kestabilan emosi dan psikologis anak. Dengan kondisi ini, anak tidak merasa menjadi orang yang paling jahat dan sangat bersalah.13

\section{Anak yang Berhadapan dengan Hukum}

Anak yang berhadapan dengan hukum adalah seorang anak yang sedang terlibat dengan masalah hukum atau sebagai pelaku tindak pidana,sementara anak tersebut belum dianggap mampu untuk mempertanggung jawabkan perbuatannya, mengingat usianya yang belum dewasa dan sedang bertumbuh berkembang, sehingga berhak untuk dilindungi sesuai dengan undang-undang. Anak yang belum berusia 14 tahun hanya dapat dikenai tindakan. 14

Anak Berhadapan dengan Hukum dinilai sebagai subyek hukum yang belum cakap dan tidak dapat memahami apa yang dilakukannya. Tetapi, pada jaman globalisasi seperti sekarang ini pembentukan

12YatiSharfinaDesiandri, "DiversiTerhadapAnak yang BerkonflikdenganHukum di Tingkat Penyidikan",USU Law Journal, Vol. 5 No. 1 (Januari 2017), 147-157

13Nashriana, Perlindungan Hukum Pidana Bagi Anak di Indonesia, Jakarta: Raja Grafindo Persada, 2012, hlm. 117

14Hartono, Penyidikan dan Penegakan Hukum Pidana Melalui Pendekatan Hukum Progresif, Jakarta: Sinar Grafika, 2010, hlm. 33-34 
karakter dan pola pikir anak sangat dipengaruhi oleh lingkungan baik rekan bergaul maupun hal-hal lain yang mudah sekali didapatnya melalui media informasi baik secara elektronik maupun non elektronik. Sehingga, suatu perbuatan pidana yang dilakukan oleh $\mathrm{ABH}$ bisa jadi memang dikehendaki oleh $\mathrm{ABH}$ dan dia juga memahami apa akibat dari perbuatan yang dilakukannya itu. Bila tindak pidana yang dilakukan anak tersebut ancaman pidananya dibawah 7 tahun dan dilakukan diversi terhadapnya, maka dikuatirkan hal itu tidak memberi efek jera dan ABH akan melaku-kannya lagi.

\section{Penyidikan Terhadap Anak}

Penyidikan terhadap perkara anak dilakukan oleh penyidik yang ditetapkan berdasarkan Keputusan Kepala Kepolisian Negara Republik Indonesia atau pejabat lain yang ditunjuk oleh Kepala Kepolisian Negara Republik Indonesia.

Syarat untuk dapat ditetapkan sebagai Penyidik, yaitu :

1. Telah berpengalaman ssebagai penyidik

2. Mempunyai minat, perhatian, dedikasi, dan memahami masalah anak

3. Telah mengikuti pelatihan teknis tentang peradilan anak

Apabila Diversi berhasil mencapai kesepakatan, Penyidik menyampaikan berita acara Diversi beserta Kesepakatan Diversi kepada ketua pengadilan negeri untuk dibuat penetapan.Sebaliknya, apabilaproses Diversi gagal, Penyidik wajib melanjutkan penyidikan dan melimpahkan perkara ke Penuntut Umum dengan melampirkan berita acara Diversi dan laporan penelitian kemasyarakatan.

\section{Penangkapan dan Penahanan terhadap Anak}

Anak yang ditangkap wajib dititipkan di LPKS. Biaya bagi setiap Anak yang ditempatkan di LPKS dibebankan pada anggaran kementerian yang menyelenggarakan urusan pemerintahan di bidang sosial.

Penahanan terhadap Anak hanya dapat dilakukan dengan syarat sebagai berikut:

1. Anak telah berumur 14 (empat belas) tahun atau lebih
2. Diduga melakukan tindak pidana dengan ancaman pidana penjara 7 (tujuh) tahun atau lebih 15

\section{Penuntutan terhadap Anak}

Penuntutan terhadap perkara Anak dilakukan oleh Penuntut Umum yang ditetapkan berdasarkan Keputu-san Jaksa Agung atau pejabat lain yang ditunjuk oleh Jaksa Agung.

Syarat untuk sebagai Penuntut Umum, sebagai berikut :

1. Telah berpengalaman sebagai penuntut umum

2. Mempunyai minat, perhatian, dedikasi, dan memahami masalah Anak

3. Telah mengikuti pelatihan teknis tentang peradilan Anak

Tugas penuntutan dilaksanakan oleh Penuntut umum yang melakukan tugas penuntutan tindak pidana yang dilakukan oleh orang dewasa

Dalam proses Diversi berhasil mencapai kesepakatan, Penuntut Umum menyampaikan berita acara Diversi beserta kesepakatan Diversi kepada ketua pengadilan negeri untuk dibuat penetapan.

Dalam proses Diversi gagal, Penuntut Umum wajib menyampaikan berita acara Diversi dan melimpahkan perkara ke pengadilan dengan melampirkan laporan hasil penelitian kemasyarakatan.16

Sistem Peradilan Pidana Anak merupakan segala unsur sistem peradilan pidana yang terkait dalam penanganan kasus-kasus ABH ( Anak Bermasalah dengan Hukum ). Polisi, Kejaksaan dan Pengadilan serta pembimbing Kemasyarakatan atau Balai Pemasyarakatan, Advokat atau pemberi bantuan, Lembaga Pembinaan Khusus Anak (LPKA), Lembaga Penempatan Anak Sementara (LPAS), dan Lembaga Penyelenggaraan Kesejahteraan Sosial (LPKS) sebagai institusi atau lembaga yang menangani $\mathrm{ABH}$ mulai dari anak bersentuhan dengan sistem peradilan, menentukan apakah anak akan ditempatkan dalam pilihan-pilihan mulai dari dibebaskan sampai dimasukkan dalam institusi penghukuman dalam koridor keadilan restoratif.

15Waluyadi, HukumPerlindunganAnak, (Bandung: MandarMaju, 2009), hlm. 1.

16Dwidja Priyatno, Wajah Hukum Pidana Asas dan Perkembangan, (Bekasi: Gramata Publishing, 2012), hlm. 308 
Menurut UU SPPA Diversi adalah pengalihan pe-nyelesaian perkara Anak dari proses peradilan pidana, yang bertujuan untuk:

- Mencapai perdamaian antara korban dan anak.

- Menyelesaikan perkara anak diluar proses peradilan.

- Menghindari anak dari perampasan kemerdekaan.

- Mendorong masyarakat untuk berpartisipasi.

- Menanamkan rasa tanggung jawab kepada anak. 17

Syarat Diversi dan syarat penahanan terhadap anak, dapat dilihat bahwa diversi dilakukan jika tindak pidana yang dilakukan oleh anak diancam dengan pi-dana penjara di bawah 7 tahun, sedangkan penahanan hanya dapat dilakukan jika ancaman pidana penjaranya tujuh tahun atau lebih. Artinya, Anak yang terhadapnya dilakukan Diversi jika ancaman pidananya di bawah 7 tahun dan tentu tidak boleh ditahan (penahanan hanya untuk ancaman pidana diatas 7 tahun).

Dalam Pasal 3 Peraturan Mahkamah Agung Nomor 4 Tahun 2014 tentang Pedoman Pelaksanaan Diversi dalam Sistem Peradilan Pidana Anak("PERMA 4/2014”), hakim anak wajib mengupayakan diversi dalam hal anak didakwa melakukan tindak pidana yang diancam dengan pidana penjara dbawah 7 tahun dan didakwa dengan tindak pidana yang diancam dengan pidana penjara 7 tahun atau lebih dalam bentuk surat dakwaan subsidaritas, alternatif, kumulatif, maupun kombinasi (gabungan).

Menurut PERMA 4 tahun 2014 Musyawarah Diversi adalah musyawarah antara pihak yang meli-batkan Anak dan orang tua/walinya, Pembimbing Ke-masyarakatan, Pekerja Sosial Profesional, Perwakilan dan pihak-pihak yang terlibat lainnya untuk mencapai kesepakatan diversi melalui pendekatan keadilan restoratif. Sedangkan Fasilitator adalah hakim yang ditunjuk oleh Ketua Pengadilan untuk menangani perkara anak yang bersangkutan. Diversi adalah pen-galihan proses pada sistem penyelesaian perkara anak yang panjang dan sangat kaku.Mediasi atau dialog atau musyawarah sebagai bagian yang tidak terpisahkan dalam diversi untuk mencapai keadilan restoratif.

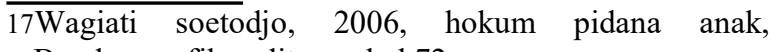
Bandung:refika aditama, hal 72
Penghukuman bagi pelaku Tindak Pidana Anak tidak kemudian mencapai keadilan bagi korban, mengingat dari sisi lain masih meninggalkan permasalahan tersendiri yang tidak terselesaikan meskipun pelaku telah dihukum. Melihat prinsip-prinsip tentang perlindungan anak terutama prinsip mengutamakan kepentingan terbaik bagi anak maka diperlukan proses penyelesaian perkara anak diluar mekanisme pidana atau biasa disebut Diversi. Institusi penghukuman bukanlah jalan untuk menyelesaikan permasalahan anak karena justru didalamnya rawan terjadi pelanggaranpelanggaran terhadap hak anak.

Oleh karena itu dibutuhkan suatu acara dan prosedur di dalam sistem yang dapat mengakomodasi penyelesaian perkara yang salah satunya adalah dengan menggunakan pendekatan keadilan restoratif, melalui suatu pembaharuan hukum yang tidak sekedar mengubah undang-undang semata tetapi juga memodifikasi sistem peradilan pidana yang ada, sehingga semua tujuan yang dikehendaki oleh hukum pun tercapai. Salah satu bentuk mekanisme restoratif justice tersebut adalah dialog yang dikalangan masyarakat Indonesia lebih dikenal dengan sebutan "musyawarah untuk mufakat". Sehingga diversi khususnya melalui konsep restoratif justice menjadi suatu pertimbangan yang sangat penting dalam menyelesaikan perkara pidana yang dilakukan oleh anak.18

Jika kesepakatan Diversi tidak dilaksanakan sepenuhnya oleh para pihak berdasarkan laporan dari Pembimbing Kemasyarakatan Balai Pemasyarakatan makan Hakim melanjutkan pemeriksaan perkara sesuai dengan Hukum Acara Peradilan Pidana anak. Hakim dalam menjatuhkan putusannya wajib mempertimbangkan pelaksanaan sebagian kesepakatan diversi.

Dalam PERMA 4 tahun 2014 dijelaskan bahwa Diversi diberlakukan terhadap anak yang telah berumur 12 tahun tetapi belum berumur 18 tahun atau telah berumur 12 tahun meskipun pernah kawin tetapi belum berumur 18 tahun, yang diduga melakukan tindak pidana. PERMA ini juga mengatur tahapan musyawarah diversi, dimana fasilitator yang ditunjuk Ketua Pengadilan wajib memberikan kesempatan kepada:

18Setya Wahyudi, 2011, Implementasi Ide Diversi dalam Pembaharuan Sistem Peradilan Pidana Anak di Indonesia, Yogyakarta, Genta Publishing 
- Anak untuk didengar keterangan perihal dakwaan.

- Orang tua/Wali untuk menyampaikan hal-hal yang berkaitan dengan perbuatan anak dan bentuk penyelesaian yang diharapkan.

- Korban/Anak, Korban/Orang tua/Wali untuk memberikan tanggapan dan bentuk penyelesaian yang diharapkan.

- Fasilitator diversi dapat memanggil perwakilan masyarakat maupun pihak lain untuk memberikan informasi untuk mendukung penyelesaian dan dapat melakukan pertemuan terpisah antara Fasilitator Diversi dengan salah satu pihak yang diketahui oleh pihak lainnya.19

\section{Penerapan putusan nomor 14/PID.Sus- Anak/2015/PT MDN terhadap anak yang melakukan tindak pidana}

Sejak disadari bahwa anak juga melakukan pelanggaran hukum, perdebatan tentang bagaimana cara yang terbaik untuk menghadapinya terus menerus berlangsung. Diversi adalah proses yang telah diakui secara Internasional sebagai cara terbaik dan paling efektif dalam menangani anak yang berhadapan dengan hukum. Intervensi terhadap anak yang berhadapan dengan hukum sangat luas dan beragam, tetapi lebih banyak menekankan pada penahanan dan penghukuman, tanpa peduli betapa ringannya pelanggaran tersebut atau betapa mudanya usia anak tersebut.

Anak yang melakukan pelanggaran hukum atau melakukan tindakan kriminal sangat dipengaruhi beberapa faktor lain diluar diri anak seperti pergaulan, pendidikan teman bermain dan sebagainya. Untuk melakukan perlindungan terhadap anak dari pengaruh proses formal sistem peradilan pidana maka timbul pemikiran manusia dan para ahli hukum dan kemanusiaan untuk membuat aturan formal tindakan mengeluarkan seorang anak yang melakukan pelang-garan hukum atau melakukan tindak pidana dari proses peradilan pidana dengan memberikan alternatif lain yang dianggap lebih baik untuk anak.

Seperti studi kasus dalampenelitianini, persetubuhan yang dilakukan oleh anak. Terdakwa dinyata-

19Mulyadi, Lilik. PengadilanAnak di Indonesia: Teori, PraktikdanPermasalahannya, Mandarmaju, Denpasar, 2005 kan bersalah menurut hasil pemeriksaan dan visum. Terdapat robekan diselaput darah korban arah jam 11,1,3,6,9 tidak dijumpai lika baru, sesuai dengan visum et repertum Nomor: 183.1/018/Med/tanggal 07Februari 2015 yang dibuat dan ditandatangani oleh Dr. Romy Sp.OG dokter pemeriksa pada Rumah Sakit Umum Gunungsitoli.

Sejak bulan April 2014 korban dan terdakwa menjalin hubungan pacaran. Terdakwa menghubungi korab melalui SMS untuk mengajak bertemu di Jalan Yos Sudarso kecamatan Gunungsitoli tepatnya di dalam warnet FLY. Setelah korban menerima pesan tersebut dan pulang sekolah korban singgah ke warnet No.4 dan bertemu dengan Terdakwa. Setelah Korban dan Terdakwa bertemu di dalam bilik warnet, Terdakwa berkata kepada Koban bahwa Terdakwa mencintai dan menyukai si Korban. Kemudian si Korban ber-tanya kepada si Terdakwa, "bagaimana itu karena beda agama kita". Terdakwa beragama Kristen dan si Korban beragama Islam. Terdakwa menjawab "tidak apa-apa, saya yang akan tobat mengikuti agama yang kamu anut" dan kemudian si Korban menjawab "asal ia saja" mendengar rayuan tersebut. Terdakwa langsung memegang dan meraba tubuh Korban dengan kedua tangannya.

Jaksa Penuntut Umum Kejaksaan Negeri Gunung-sitoli tertanggal 02 Maret 2015, No. Reg. Perkara: PDM-23/GNSTO/02.15 menuntut Terdakwa sebagai berikut:

1. Menyatakan Terdakwa An. Anak bersalah melakukan Tindak Pidana persetubuhan anak di bawah umur, sebagaimana diatur dalam Pasal 81 ayat (2) Undang-undang nomer 23 Tahun 2002 tentang Pelindungan Anak dalam dakwaan primair

2. Menjatuhkan pidana terhadap Terdakwa An. Anak dengan pidana penjara selama 2 (dua) tahun pen-jara dan denda sebesar Rp. 30.000.000 (tiga puluh juta rupiahSubsidair 3 (tiga) bulan kurungan di kurangkan sepenuhnya selama anakmenjalani masa tahanan sementara

3. Membebankan kepada Terdakwa yang berhadapan dengan hukum membayar biaya perkara sebesar Rp. 2.000 ( dua ribu rupiah)

Putusan Pengadilan Negeri Gunungsitokli tanggal 16 Maret 2015, Nomor: 1/Pid.Sus-Anak/2015/ 
PN-GST sebagai berikuit:

1. Menyatakan Terdakwa yang berhadapan dengan hukum, telah terbukti sacara sah dan meyakinkan bersalah melakukan tindak pidana “ Dengan sengaja membujuk Korban untuk melakukan persetubuhan dengannya"

2. Menjatuhkan pidana kepada terdakwa dengan pidana penjara selama 6 (enam) bulan

3. Menetapkan bawa pidana yang dijatuhkan tidak usah dijalani, kecuali jika dikemudian hari ada Putusan Hakim yang menentukan lain disebabkan karena Terdakwa yang berhadapan dengan hukum melakukan tindak pidana sebelum masa percobaan selama 1 (satu) tahun berakhir

4. Menghukum Terdakwa membayar denda sebesar Rp. 1.000.000,- (satu juta rupiah) dengan keten-tuan apabila denda tidak dibayar maka diganti dengan Pidana Kurungan selama 3(tiga) bulan Menetapkan barang bukti berupa :

1. 1 (satu) buahcelanadalamberwarnacoklatdikembalikankepada Korban

2. 3 (tiga) lembarfoto proses pertunanganTerdakwa-dan Korban padatanggal 11 Maret 2015 tetap di dalamberkasperkara No. 1/Pid/Sus-Anak/2015/ PN.Gst

3. Membebankan biaya perkara ini kepada Terdakwa sebesar Rp.2.000,-(dua ribu rupiah)

Menimbang, bahwa Jaksa Penuntut Umum mengajukan permohonan banding pada tanggal 26 Maret 2015 yang pada pokokinya bahwa hukuman yang dijatuhkan oleh Pengadilan Negeri Gunungsitoli dengan hukum Terdakwa belum memadai bila dilihat dari segi Edukatif, Prepentif, Korektif maupun Represif.

Menimbang, bahwa Pengadilan Tinggi setelah mempelajari dengan seksama memori banding Jaksa Penuntut Umum ternyata hanya merupakan ulangan dari surat tuntutan Jaksa Penuntut Umum, tidak ada hal-hal yang baru dan hal itu semua telah dipertimbangkan dengan seksama oleh Hakim Tingkat Pertama dalam putusannya oleh karena itu alasan-alasan dan keberatan-keberatan dalam memori banding Kasa Penuntut Umum haruslah dikesampingkan.
Menurut hasil putusan kasus persetubuhan yang dilakukan oleh anak, Hakim Pengadilan Negeri Tinggi melakukan proses Diversi terhadap anak yang berhadapan dengan hukum dengan menetapkan bahwa pidana yang di jatuhkan kepada Terdakwa tidak usah dijalani, kecuali jika dikemudian hari ada putusan Hakim yang menentuikan lain disebabkan karena anak yang berhadapan dengan hukum melakukan tindak pidana sebelum masa percobaan selama 1 (satu) tahun berakhir.

\section{Kesimpulandan Saran}

Diversi adalah proses yang telah diakui secara Internasional sebagai cara terbaik dan paling efektif dalam menangani anak yang berhadapan dengan hukum. Pelaksanaan Diversi dilatarbelakangi keinginan menghindari efek negatif terhadap jiwa dan perkembangan anak oleh keterlibatannya dengan sistem peradilan pidana. Pelaksanaan Diversi oleh aparat penegak hukum didasari oleh kewenangan aparat penegak hukum yang disebut discretion atau diskresi.Kunci utama untuk menjadikan anak seba-gai potensi Negara dalam rangka keberlangsungan kehidupan dan kejayaan bangsa adalah bagaimana komitmen pemerintah untuk menjadikan anak sebagai prioritas utama dalam pembangunan. Upaya nyata adalah menciptakan lingkungan yang mengutamakan perlindungan bagi anak, menghidupkan nilai - nilai dan tradisi yang memajukan harkat dan martabat anak, mengeksplorasi dan memobilisasi sumber daya untuk mendukung penyelenggaraan perlindungan anak. Namun, semua itu tergantung bagaimana negeri ini menemukan kepemimpinan yang peduli anak.Semua pihak harus konsentrasi dan serius dalam mempersiapkan SDM, sarana dan prasarana untuk mendukung Sistem Peradilan Anak terutama Fasilitator. Hakim Peradilan Anak dan Pengadilan sebagai benteng terakhir dalam proses penyelesaian anak yang berhadapan hukum di Pengadilan.Didalam penerapan diversi terhadap putusan tersebut,dengan demikian bahwa harus adanya pemahaman terlebih dahulu terhadap masyarakat akan sisi baik nya diversi terhadap anak yang melakukan 
tindak pidana, terlebih diversi dilakukan agar kiranya dapat memperbaiki pola pikir seorang anak agar dapat menjadi orang yang lebih baik kedepannya.Maka itu setidaknya di dalam proses pengadilan kiranya hakim dapat mempertimbangkan proses diversi terhadap anak yang melakukan tindak pidana,serta mempertimbangkan hak-hak anak sebagai pelaku dibawah umur.

Aparat kepolisian dan masyarakat harus bersinergi dan membangun persepsi yang sama tentang upaya diversi dan restorative justice. Upaya diversi bertu-juan untuk memberikan alternatif penyelesaian suatu perkara terhadap anak sebagai pelaku tindak kejahatan, sehingga antara pihak korban, pelaku, keluarga korban, keluarga pelaku dan masyarakat di berikan pemaha-man yang samaAparat penegak hukum khususnya pihak Penuntut Umum Anak, agar meningkatkan perannya dalam memperhatikan nasib dan kepentingan pelaku anak. Sehingga tidak hanya memperhatikan hak-hak sebagai korban saja untuk dilindungi, tetapi juga hak-hak anak sebagai pelaku dapat benar-benar dilindungi.Orang tua harus ikut dalam memberikan perlindungan terhadap anak dengan memenuhi hak-hak anak, melindungi kepentingan anak dan semakin meningkatkan pengawasan terhadap lingkungan dan tempat anak bermain.

\section{Daftar Pustaka}

Ali, Zainuddin. 2013. PenelitianHukum. CetakanKe-empat. Jakarta: SinarGrafika.

BadanKoordinasiKeluargaBerencana Nasional. 2002. Pelecehan SeksualoKekerasan Seksual. Jakarta : BKKBN.

C.S.T. Kansildan Christine S.T. Kansil. 2007. PokokPokokHukumPidana. Jakarta: PT. PradnyaParamita.

Desiandri, YatiSharfina. 2017. "DiversiTerhadapAnak yang BerkonflikdenganHukum di Tingkat Penyidikan".USU Law Journal. Vol. 5 No. 147-157

Djamil, M. Nasir. 2013. AnakBukanuntukDihukum. Jakarta: SinarGrafika.
Gultom, Maidin. 2010. PerlindunganHukumTerhadapAnakDalamSistemPeradilanPidanaAnak di Indonesia. Bandung: RedikaAditama.

Hartono. 2010. Penyidikan dan Penegakan Hukum Pidana Melalui Pendekatan Hukum Progresif. Jakarta: Sinar Grafika.

Kenneth Polk, dalam Made Ayu Catra MS, Diversi dalam Sistem Peradilan Pidana Anak di Indonesia. Thesis. Denpasar: Program Pasca sarjana Udayana.

Lembaga Bantuan Hukum Jakarta. 2012. Mengawal Perlindungan Anak Berhadapan Dengan Hukum. CetakanKesatu. Jakarta: LBH Jakarta.

Mulyadi, Lilik. 2005. PengadilanAnak di Indonesia: Teori, PraktikdanPermasalahannya, Mandarmaju. Denpasar.

Nashriana. 2011. PerlindunganHukumPidanaBagiAnak di Indonesia. Jakarta: PT. Raja GrafindoPersada.

2012. PerlindunganHukumPidanaBagiAnak di Indonesia. Jakarta: Raja GrafindoPersada.

Priyatno, Dwidja. 2012. WajahHukumPidanaAsasdanPerkembangan. Bekasi: Gramata Publishing.

Soekanto, Soerjono. 1986. PengantarPenelitianHukum. cet: 3. Jakarta : UI-Press.

Soekanto, Soerjonodan Sri Mamudji. 2013. PenelitianHukumNormatif( SuatuTinjauanSingkat). cet.

7. Jakarta: Raja GrafindoPersada.

Soetodjo, Wagiati. 2006. Hukum Pidana Anak. Band-ung: Refika Aditama.

Styowati, Irina. 1990. AspekHukumPerlindunganAnak. Jakarta: BumiAksara.

Sudarsono. 2007.Kamus Hukum. Cetakan Kelima. Jakarta: P.T. Rineka Cipta.

Wahyudi, Setya. 2011.Implementasi Ide Diversi dalam Pembaharuan Sistem Peradilan Pidana Anak di Indonesia.Yogyakarta: Genta Publishing.

Waluyadi. 2009. HukumPerlindunganAnak. Bandung:

MandarMaju. 
Wiyono, R. 2016. SistemPeradilanPidanaAnak di Indonesia. Jakarta: SinarGrafika.

\section{PERATURAN PERUNDAN-UNDANGAN}

UU No. 35 Tahun 2014 Tentangperubahanatas UU No. 23 Tahun 2002 TentangPerlindunganAnak

Undang-UndangNomor 4 Tahun 1979 tentangkesejahteraananak.

\section{PUTUSAN}

PutusanNomor 14/PID.SUS-ANAK/2015/PT.MDN 